\title{
The Application of Lean Methods in Corporate Sustainability-A Systematic Literature Review
}

\author{
Frank Bertagnolli *(D), Kerstin Herrmann, Isabel Rittmann (D) and Tobias Viere (D) \\ INEC HS Pforzheim, 75175 Pforzheim, Germany; inec@hs-pforzheim.de (K.H.); \\ isabel.rittmann@hs-pforzheim.de (I.R.); tobias.viere@hs-pforzheim.de (T.V.) \\ * Correspondence: frank.bertagnolli@hs-pforzheim.de; Tel.: +49-7231-28-6372
}

Citation: Bertagnolli, F.; Herrmann,

K.; Rittmann, I.; Viere, T. The

Application of Lean Methods in

Corporate Sustainability-A

Systematic Literature Review.

Sustainability 2021, 13, 12786.

https://doi.org/10.3390/su132212786

Academic Editors: Daryl Powell, David Romero and Paolo Gaiardelli

Received: 26 October 2021

Accepted: 16 November 2021

Published: 19 November 2021

Publisher's Note: MDPI stays neutral with regard to jurisdictional claims in published maps and institutional affiliations.

Copyright: (C) 2021 by the authors Licensee MDPI, Basel, Switzerland. This article is an open access article distributed under the terms and conditions of the Creative Commons Attribution (CC BY) license (https:/ / creativecommons.org/licenses/by/ $4.0 /)$.

\begin{abstract}
This paper reviews the application of lean methods for corporate sustainability and highlights demands for future research. With the help of a systematic literature review, papers at the interface of lean and sustainability were identified and matched to a standardized list of lean methods to assess their frequency in the context of sustainability. In a further step, papers containing actual case studies were analyzed in more detail regarding specific application settings, sustainability dimensions, measurability of sustainability impact, and other criteria. The quantitative analysis of 363 publications shows frequent use of lean methods such as just in time and value stream mapping in the context of sustainability, and a surprisingly low use of other approaches such as karakuri, milk run, or chaku chaku. The in-depth analysis of 81 case studies reveals the primacy of intracompany and ecological assessments in the lean context, while social and inter-company aspects remain rather underexposed. This study complements existing research on lean and sustainability by systematically analyzing specific lean methods in the context of sustainability and by further exploring the sustainability characteristics of such lean applications.
\end{abstract}

Keywords: lean; green; sustainability; corporate sustainability; literature review

\section{Introduction}

Sustainable development is a globally accepted and pursued objective, which is manifested in the United Nations Sustainable Development Goals [1]. These 17 high-level political goals have not only been integrated into regional, national, and local strategies and policies, but have also gained strategic importance in business, see, e.g., [2]. Lately, since the framing by Elkington of the term "triple bottom line" [3], the business challenge of balancing environmental, social, and economic performance is an important aspect of management research and practice, which is often referred to as corporate sustainability. The exact definition and the methodological scope of corporate sustainability are still under discussion to date. They range from "a firm's attempt to respond to environmental and social issues" to "a bundle of activities fully integrated into a firm's overall strategy that contribute effectively to the welfare of current and future generations through protecting and enhancing the resilience of the biosphere, social equity and cohesion, and economic prosperity" [4] (p. 333). Without a doubt, corporate sustainability needs to contribute to ensuring sustainable consumption and production patterns. Using natural resources efficiently and reducing waste generation substantially are key targets to achieve the respective aspects of United Nations Sustainable Development Goal 12 [5]. The wise use of resources and waste elimination are key targets of sustainable development and corporate sustainability. Resource efficiency and waste elimination are equally significant for lean strategies as well.

Lean production originated from scarce resources and the necessity to eliminate waste in all processes [6] (p. 13). Lean production focuses on the customer and strives for continuous improvement of processes and products [7] (p. 7). Therefore, lean methods and tools have "been widely implemented by manufacturing organizations to achieve operational 
excellence, and in this way meet both traditional and contemporary organizational objectives such as profitability, efficiency, responsiveness, quality and customer satisfaction" [8] (p. 170).

Lean production covers a broad field of tools, methods, and concepts. Liker, for example, describes 14 principles underlying the Toyota Production System (TPS), which is practiced at Toyota manufacturing plants around the world [9] (p. 19). He divides the principles into four categories-philosophy, process, people/partners, and problem solving. Tools and quality improvement methods, such as just in time, kaizen, one piece flow, jidoka, and heijunka, form a subset. Clarke demonstrates the variety of principles, methods, and tools by describing and exploring examples from practice, such as the structure of the Mercedes-Benz Production System [10] (p. 160). A systematic, non-overlapping overview of lean methods and concepts is provided by the German Association of Engineers (Verein Deutscher Ingenieure, VDI) in VDI guideline 2870 [11]. The VDI guidelines are developed by experts in working groups. The VDI guideline about "Lean production systems: Basic principles, introduction, and review" distinguishes a total of 35 methods classified into 8 superordinate principles and states the contribution of the individual methods to the target parameters of cost, quality, and time. To the knowledge of the authors, this VDI guideline provides the most comprehensive and standardized overview of lean methods.

Given that corporate sustainability and lean production pursue similar goals, the interplay of the multitude of lean methods and corporate sustainability is of mutual interest for practitioners and researchers in both domains. Hence, this paper examines which lean methods are used in the context of corporate sustainability (research question 1) and which specific characteristics of corporate sustainability are addressed by lean applications (research question 2). The next section outlines the research methodology of a systematic literature review; Section 3 presents its results, while Section 4 provides interpretation, discussion, and limitations of this research, before it concludes by pointing out future research directions.

\section{Methodology}

A systematic literature review is a comprehensible and reproduceable research method to determine the current state of science in a subject area and to identify research gaps and further research needs [12,13]. According to Denyer and Tranfield [12], a systematic literature review includes the steps of question formulation, locating studies, study selection and evaluation, analysis and synthesis, and reporting and using results.

Figure 1 illustrates the design of the respective literature review. The research questions "Which lean methods are used in the context of corporate sustainability?" and "Which specific characteristics of corporate sustainability are addressed by lean applications?" have been derived in the previous section. 


\section{Question formulation}

"Which lean methods are used in the context of corporate sustainability?"

"Which specific characteristics of corporate sustainability are addressed by lean applications?"

\section{Locating studies}

Search period: 1990 to July 2020

Search engines: ScienceDirect (Elsevier), Emerald Insight, SpringerLink (carried out via Google Scholar with results limited to Springer publications), Taylor \& Francis Online, Wiley Online Library, EBSCO EconLit with Full Text

Search string 1: "lean" AND ("green" OR "sustainability" OR "environment" OR

"Corporate Social Responsibility")

Search string 2: "lean" AND "green" OR "lean" AND "sustainability" OR "lean" AND "environment" OR "lean" AND "Corporate Social Responsibility"

inclusion criteria: (peer-reviewed) journal article, conference paper, book chapter

exclusion criteria: unpublished conference paper, working paper, unpublished articles and books, textbooks

(section 2)

$$
2876
$$

Study selection and evaluation

total number of publications found: 2876 total number of publications used: 363

(section 3.1)

47

Triangulation (meta studies): 47

(section 3.2)

81

Analysis and synthesis 1

Research question 1 (lean methods): 363

(section 3.3)

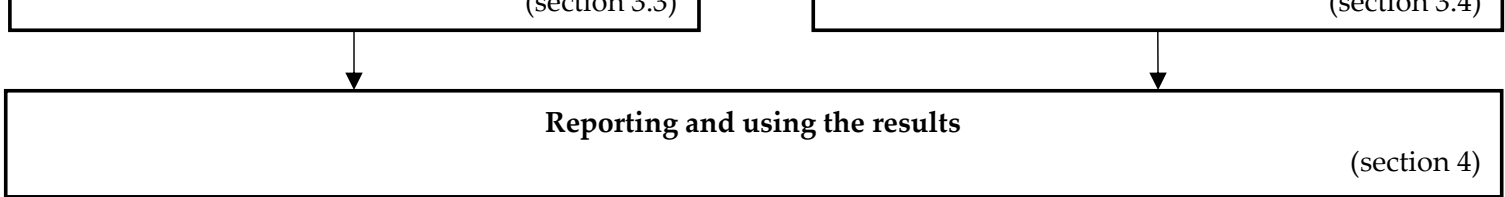

Figure 1. Literature review design.

Six scientific databases were selected as literature sources. The four databases ScienceDirect (Elsevier), Emerald Insight, Springer Link and Taylor \& Francis Online are all major scientific publishers. For the literature search to be as comprehensive as possible, 
the two scientific databases Wiley Online Library and EBSCO EconLit with Full Text were also selected. For the search within the databases, pairs of terms from the fields of lean management and sustainability are chosen and combined into search strings using Boolean operators and brackets. Table 1 shows search engines and terms used for this study. The literature review covers publications between 1990, where the terms lean and lean management were first mentioned by Womack et al. [6], and July 2020. It includes (peer-reviewed) journal articles, conference papers (if published in a journal or a book), book contributions, and book chapters. The review excludes unpublished conference papers, working papers, textbooks, and unpublished articles and textbooks. The search terms were applied to abstract, title, and keywords. A total of 2876 publications was identified in this second step.

Table 1. Lean principles and methods according to VDI 2870 and additional search terms and abbreviations.

\begin{tabular}{|c|c|c|}
\hline Principle Following VDI 2870 & Method Following VDI 2870 & $\begin{array}{c}\text { Further Search Terms and } \\
\text { Abbreviations }\end{array}$ \\
\hline Pull principle & $\begin{array}{l}\text { just in time } \\
\text { Kanban } \\
\text { supermarket } \\
\text { just in sequence } \\
\text { levelling } \\
\text { milk run } \\
\end{array}$ & $\begin{array}{l}\text { JIT } \\
\text { JIS }\end{array}$ \\
\hline Zero defects principle & $\begin{array}{c}\text { Six Sigma } \\
\text { Poka Yoke } \\
\text { autonomation } \\
\text { statistical process control } \\
5 \times \text { why } \\
\text { A3 method } \\
\text { Ishikawa diagram } \\
\text { 8D report } \\
\text { short control loops } \\
\text { worker self-check }\end{array}$ & $\begin{array}{c}6 \sigma \\
\text { jidoka } \\
\text { SPC } \\
5 \mathrm{w} \\
\text { A3 } \\
\text { 8D }\end{array}$ \\
\hline Flow principle & $\begin{array}{l}\text { value stream planning } \\
\text { quick changeover } \\
\text { one piece flow } \\
\text { first in first out } \\
\text { U layout }\end{array}$ & $\begin{array}{c}\text { value stream mapping, VSM } \\
\text { single minute exchange of } \\
\text { die, SMED } \\
\text { FIFO } \\
\text { U cell }\end{array}$ \\
\hline Continuous improvement & $\begin{array}{c}\text { benchmarking } \\
\text { audit } \\
\text { PDCA (plan, do, check, act) } \\
\text { cardboard engineering } \\
\text { idea management }\end{array}$ & \\
\hline Avoidance of waste & $\begin{array}{l}\text { total productive maintenance } \\
\text { waste analysis } \\
\text { low cost automation } \\
\text { Chaku Chaku }\end{array}$ & $\begin{array}{c}\text { TPM } \\
\text { LCA, LCIA (low cost } \\
\text { intelligent } \\
\text { automation), karakuri }\end{array}$ \\
\hline Standardization & $\begin{array}{c}5 \mathrm{~S} \\
\text { process standardization }\end{array}$ & $5 \mathrm{~S}$ \\
\hline Visual management & $\begin{array}{c}\text { Andon } \\
\text { shop floor management }\end{array}$ & SFM \\
\hline $\begin{array}{l}\text { Employee orientation and } \\
\text { management by objectives }\end{array}$ & $\begin{array}{c}\text { Hancho } \\
\text { target management }\end{array}$ & \\
\hline
\end{tabular}


The titles, abstracts, and keywords of all identified papers were screened using consistent criteria to exclude irrelevant publications and duplicates. The screening led to the exclusion of 159 duplicates, 25 publications that did not meet the formal requirements, and 67 publications that revealed none or only one of the search terms. There were 2262 publications that did not address the topic of lean and sustainability as specified in Section 1; for instance, environment is often used with a different meaning such as "working environment", "competitive environment", etc. Further examples are sustainability in the sense of longer lasting, as well as "lean burn" and "environment", where lean burn refers to the combustion of gases. Therefore, a further 2262 publications were excluded.

The remaining population of 363 publications was examined further to validate and answer the research questions:

- Within the given population, all meta-studies and literature reviews were identified. A qualitative content analysis of these 47 publications was used to better understand if and how previous research has covered the interaction of lean methods and corporate sustainability. Hence, this analysis served as a triangulation of the suitability and focus of the research questions of this paper.

- The full texts excluding bibliographies of all 363 publications were searched for the number of mentions of lean methods according to VDI guideline 2870 [11] to answer the first research question. If appropriate, common abbreviations and additional terms were added to the search for each method (cp. Table 1).

- Finally, all relevant publications were screened for "real world" case studies. The 81 publications with case study content were identified and included in a full text analysis to identify their characteristics with regard to corporate sustainability to answer the second research question.

\section{Results}

\subsection{Bibliometric Evaluation}

The selection and evaluation of all search results revealed that 363 scientific publications are of interest for this study, dating back to a first publication on lean and sustainability published in 1996. Figure 2 shows a steady increase in publications since 2010. The 204 publications from within the last three years (2018-2020) represent $56 \%$ of all publications and underline the increasing attention that this topic receives. 
a) Journal of Cleaner Production

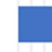

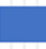

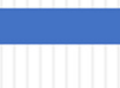

Procedia CIRP

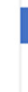

International Journal of Production Economics

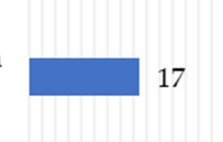

International Journal of Lean Six Sigma

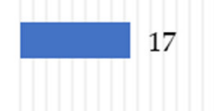

Production Planning \& Control 16
82

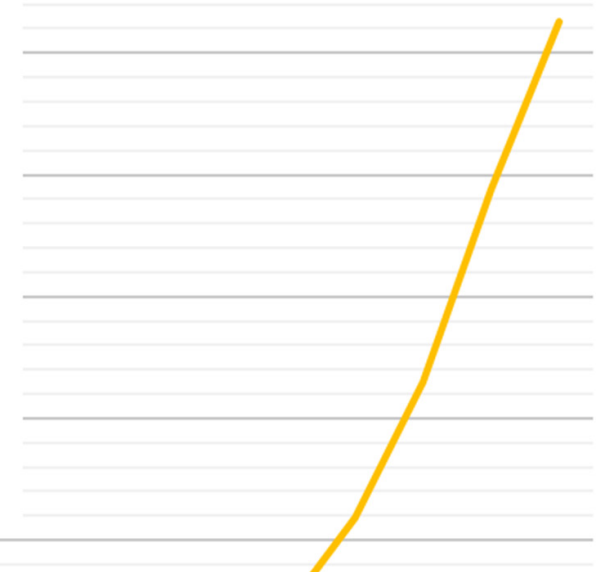

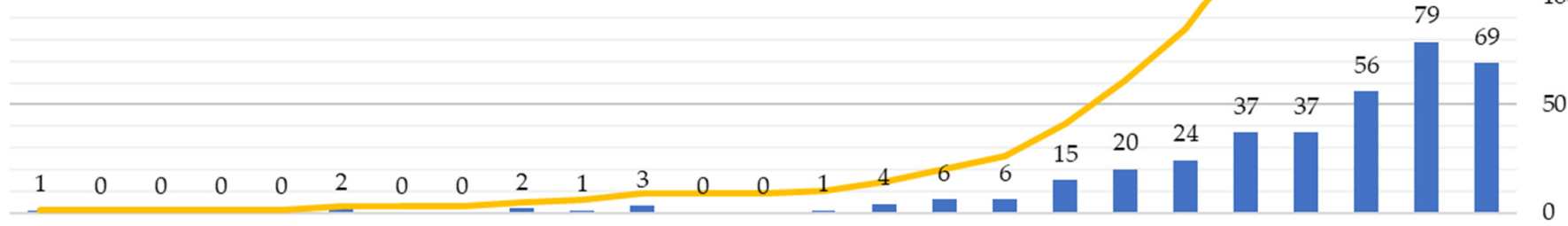

$1996199719981999200020012002200320042005200620072008200920102011201220132014201520162017201820192020^{*}$

Figure 2. (a) Top five journals with the most publications and (b) the number of publications on lean and corporate sustainability from 1996-2020.

The relevant publications are published in a total of 89 different journals. With 83 publications, almost a quarter of all publications on lean and sustainability have appeared in the Journal of Cleaner Production, a sustainability-related journal. More than 200 publications have been published in journals focusing on lean and production-related topics.

\subsection{Meta-Studies and Literature Reviews}

There are 47 out of the 363 publications that are classified as meta-studies and literature reviews. These meta-studies and literature reviews at the interface of lean and corporate sustainability have been analyzed in terms of their topicality, their scope (number of publications considered), and their thematic focus. Table 2 shows that only a few of the existing studies and reviews cover the last three years, which accounts for the majority of all papers identified within this study. Consequently, most existing meta-studies and literature reviews consider far fewer publications compared to this study. Some of the existing literature reviews and meta-studies are industry-specific and, for instance, focus on lean construction (e.g., [14]); others focus on partial aspects, such as lean and green product development or the supply chain (e.g., $[15,16])$. The existing meta-studies studies remain at a philosophical level (e.g., $[17,18])$ or address the elimination of waste at an aggregated level (e.g., $[19,20])$. 
Table 2. Literature reviews and meta-studies on lean management and sustainability (full references are provided in the Supplementary Material).

\begin{tabular}{|c|c|c|c|c|}
\hline Author & Title & $\begin{array}{l}\text { Survey } \\
\text { Period }\end{array}$ & $\begin{array}{c}\text { Quantity of } \\
\text { Papers Included }\end{array}$ & Special Focus \\
\hline Alves et al. (2016) [20] & $\begin{array}{l}\text { Sustainability, Lean and Eco-Efficiency } \\
\text { Symbioses }\end{array}$ & 2001-2015 & 83 & \\
\hline Babalola et al. (2019) [21] & $\begin{array}{l}\text { Implementation of lean practices in the } \\
\text { construction industry: A systematic review }\end{array}$ & 1996-2018 & 102 & $\begin{array}{c}\text { lean } \\
\text { construction }\end{array}$ \\
\hline Baliga et al. (2020) [16] & $\begin{array}{l}\text { The effect of motivators, supply, and lean } \\
\text { management on sustainable supply chain } \\
\text { management practices and performance }\end{array}$ & 1988-2018 & 277 & supply chain \\
\hline Bhatt et al. (2020) [22] & $\begin{array}{l}\text { Sustainable manufacturing. Bibliometrics and } \\
\text { content analysis }\end{array}$ & $\mathrm{N} / \mathrm{A}$ & 162 & \\
\hline $\begin{array}{l}\text { Bhattacharya et al. } \\
\text { (2019) [23] }\end{array}$ & $\begin{array}{l}\text { Lean-green integration and its impact on } \\
\text { sustainability performance: A critical review }\end{array}$ & 2006-2018 & 80 & \\
\hline Caldera et al. (2017) [24] & $\begin{array}{l}\text { Exploring the role of lean thinking in } \\
\text { sustainable business practice: A systematic } \\
\text { literature review }\end{array}$ & 1995-2015 & 102 & \\
\hline $\begin{array}{l}\text { Carvajal-Arango et al. } \\
\text { (2019) [14] }\end{array}$ & $\begin{array}{l}\text { Relationships between lean and sustainable } \\
\text { construction: Positive impacts of lean } \\
\text { practices over sustainability during } \\
\text { construction phase }\end{array}$ & 1998-2018 & 117 & $\begin{array}{c}\text { lean } \\
\text { construction }\end{array}$ \\
\hline Cherrafi et al. (2016) [25] & $\begin{array}{l}\text { The integration of lean manufacturing, Six } \\
\text { Sigma and sustainability: A literature review } \\
\text { and future research directions for developing } \\
\text { a specific model }\end{array}$ & 1990-2015 & 118 & Six Sigma \\
\hline Cherrafi et al. (2017B) [19] & $\begin{array}{l}\text { Barriers in Green Lean implementation: a } \\
\text { combined systematic literature review and } \\
\text { interpretive structural modelling approach }\end{array}$ & $\mathrm{N} / \mathrm{A}$ & 91 & \\
\hline Chugani et al. (2017) [26] & $\begin{array}{l}\text { Investigating the green impact of Lean, Six } \\
\text { Sigma and Lean Six Sigma }\end{array}$ & $\mathrm{N} / \mathrm{A}$ & 70 & Six Sigma \\
\hline Ciccullo et al. (2018) [27] & $\begin{array}{l}\text { Integrating the environmental and social } \\
\text { sustainability pillars into the lean and agile } \\
\text { supply chain management paradigms: A } \\
\text { literature review and future research } \\
\text { directions }\end{array}$ & 1999-2017 & 73 & $\begin{array}{l}\text { lean and agile } \\
\text { supply chain } \\
\text { management }\end{array}$ \\
\hline $\begin{array}{l}\text { Cruz-Villazon et al. } \\
\text { (2019) [28] }\end{array}$ & $\begin{array}{l}\text { Lean Thinking: A Useful Tool to Integrate } \\
\text { Sustainability into Project Management }\end{array}$ & 2000-2016 & 20 & lean thinking \\
\hline Dieste et al. (2019) [29] & $\begin{array}{l}\text { The relationship between lean and } \\
\text { environmental performance: Practices and } \\
\text { measures }\end{array}$ & 1993-2018 & 72 & \\
\hline $\begin{array}{l}\text { Duarte and } \\
\text { Cruz-Machado (2011) [30] }\end{array}$ & $\begin{array}{l}\text { Manufacturing paradigms in Supply Chain } \\
\text { Management }\end{array}$ & 2000-2009 & $\mathrm{N} / \mathrm{A}$ & supply chain \\
\hline Dubey and Ali (2015) [31] & $\begin{array}{l}\text { Exploring antecedents of extended supply } \\
\text { chain performance measures }\end{array}$ & $\mathrm{N} / \mathrm{A}$ & 275 & supply chain \\
\hline Dües et al. (2013) [32] & $\begin{array}{l}\text { Green as the new Lean: how to use Lean } \\
\text { practices as a catalyst to greening your supply } \\
\text { chain }\end{array}$ & 1990-2013 & $\mathrm{N} / \mathrm{A}$ & \\
\hline Engin et al. (2019) [33] & $\begin{array}{l}\text { Lean and Green Supply Chain Management: } \\
\text { A Comprehensive Review }\end{array}$ & 2000-2017 & 41 & supply chain \\
\hline Farias et al. (2019A) [34] & $\begin{array}{l}\text { Criteria and practices for lean and green } \\
\text { performance assessment: Systematic review } \\
\text { and conceptual framework }\end{array}$ & 1996-2018 & 65 & \\
\hline
\end{tabular}


Table 2. Cont.

\begin{tabular}{|c|c|c|c|c|}
\hline Author & Title & $\begin{array}{l}\text { Survey } \\
\text { Period }\end{array}$ & $\begin{array}{c}\text { Quantity of } \\
\text { Papers Included }\end{array}$ & Special Focus \\
\hline $\begin{array}{l}\text { Freitas and Costa } \\
\text { (2017) [35] }\end{array}$ & $\begin{array}{l}\text { Impacts of Lean Six Sigma over } \\
\text { organizational sustainability }\end{array}$ & 2003-2014 & 48 & Six Sigma \\
\hline $\begin{array}{l}\text { Gaikwad and Sunnapwar } \\
\text { (2020) [36] }\end{array}$ & $\begin{array}{l}\text { An integrated Lean, Green and Six Sigma } \\
\text { strategies }\end{array}$ & 1990-2017 & 105 & Six Sigma \\
\hline Garza-Reyes (2015B) [37] & $\begin{array}{l}\text { Lean and green-a systematic review of the } \\
\text { state of the art literature }\end{array}$ & 1997-2014 & 59 & \\
\hline Garza-Reyes (2015A) [38] & Green lean and the need for Six Sigma & $\mathrm{N} / \mathrm{A}$ & 57 & Six Sigma \\
\hline $\begin{array}{l}\text { Hallam and Contreras } \\
\text { (2016) [17] }\end{array}$ & Integrating lean and green management & 1996-2016 & 60 & \\
\hline $\begin{array}{l}\text { Hartini and Ciptomulyono } \\
\text { (2015) [39] }\end{array}$ & $\begin{array}{l}\text { The Relationship between Lean and } \\
\text { Sustainable Manufacturing on Performance: } \\
\text { Literature Review }\end{array}$ & 2000-2014 & 58 & \\
\hline Henao et al. (2019) [40] & $\begin{array}{l}\text { Lean manufacturing and sustainable } \\
\text { performance: Trends and future challenges }\end{array}$ & 1990-2017 & 69 & \\
\hline Jamil and Fathi (2016) [18] & $\begin{array}{l}\text { The Integration of Lean Construction and } \\
\text { Sustainable Construction: A Stakeholder } \\
\text { Perspective in Analyzing Sustainable Lean } \\
\text { Construction Strategies in Malaysia }\end{array}$ & $\mathrm{N} / \mathrm{A}$ & $\mathrm{N} / \mathrm{A}$ & $\begin{array}{c}\text { lean } \\
\text { construction }\end{array}$ \\
\hline $\begin{array}{l}\text { de Souza and Dekkers } \\
\text { (2019) [41] }\end{array}$ & $\begin{array}{l}\text { Adding Sustainability to Lean Product } \\
\text { Development }\end{array}$ & $\mathrm{N} / \mathrm{A}$ & 96 & $\begin{array}{l}\text { lean product } \\
\text { development }\end{array}$ \\
\hline $\begin{array}{l}\text { Johansson and Sundin } \\
\text { (2014) [15] }\end{array}$ & $\begin{array}{l}\text { Lean and green product development: two } \\
\text { sides of the same coin? }\end{array}$ & 2000-2012 & 102 & $\begin{array}{l}\text { lean and } \\
\text { green product } \\
\text { development }\end{array}$ \\
\hline $\begin{array}{l}\text { Kaswan and Rathi } \\
\text { (2019) [42] }\end{array}$ & $\begin{array}{l}\text { Analysis and modeling the enablers of Green } \\
\text { Lean Six Sigma implementation using } \\
\text { Interpretive Structural Modeling }\end{array}$ & 1973-2018 & $\mathrm{N} / \mathrm{A}$ & Six Sigma \\
\hline Li et al. (2020A) [43] & $\begin{array}{l}\text { A systematic review of lean construction in } \\
\text { Mainland China }\end{array}$ & 1996-2019 & 307 & $\begin{array}{l}\text { lean } \\
\text { construction } \\
\text { in China }\end{array}$ \\
\hline $\begin{array}{l}\text { Lopes de Sousa Jabbour } \\
\text { et al. }(2020)[44]\end{array}$ & $\begin{array}{l}\text { Sustainable development in Asian } \\
\text { manufacturing SMEs: Progress and directions }\end{array}$ & $2006-2019$ & 36 & $\begin{array}{l}\text { small medium } \\
\text { enterprises } \\
(\mathrm{SME}) \text { in Asia }\end{array}$ \\
\hline $\begin{array}{l}\text { Marco-Ferreira et al. } \\
\text { (2020) [45] }\end{array}$ & $\begin{array}{l}\text { Lean and Green: practices, paradigms and } \\
\text { future prospects }\end{array}$ & 2014-2018 & 107 & \\
\hline Marhani et al. (2013) [46] & $\begin{array}{l}\text { Sustainability Through Lean Construction } \\
\text { Approach: A Literature Review }\end{array}$ & 1992-2012 & $\mathrm{N} / \mathrm{A}$ & $\begin{array}{c}\text { lean } \\
\text { construction }\end{array}$ \\
\hline $\begin{array}{l}\text { Martínez León and } \\
\text { Calvo-Amodio (2017) [47] }\end{array}$ & $\begin{array}{l}\text { Towards lean for sustainability: } \\
\text { Understanding the interrelationships between } \\
\text { lean and sustainability from a systems } \\
\text { thinking perspective }\end{array}$ & 1987-2014 & 72 & \\
\hline $\begin{array}{l}\text { Martínez-Jurado and } \\
\text { Moyano-Fuentes } \\
(2014)[48]\end{array}$ & $\begin{array}{l}\text { Lean Management, Supply Chain } \\
\text { Management and Sustainability: A Literature } \\
\text { Review }\end{array}$ & 1990-2013 & 58 & \\
\hline $\begin{array}{l}\text { Mellado and Lou } \\
\text { (2019) [49] }\end{array}$ & $\begin{array}{l}\text { Building information modelling, lean and } \\
\text { sustainability: An integration framework to } \\
\text { promote performance improvements in the } \\
\text { construction industry }\end{array}$ & 2000-2018 & 215 & $\begin{array}{c}\text { lean } \\
\text { construction }\end{array}$ \\
\hline $\begin{array}{l}\text { Mollenkopf et al. } \\
\text { (2010) [50] }\end{array}$ & Green, lean, and global supply chains & 1990-2009 & $\mathrm{N} / \mathrm{A}$ & supply chain \\
\hline
\end{tabular}


Table 2. Cont.

\begin{tabular}{|c|c|c|c|c|}
\hline Author & Title & $\begin{array}{l}\text { Survey } \\
\text { Period }\end{array}$ & $\begin{array}{c}\text { Quantity of } \\
\text { Papers Included }\end{array}$ & Special Focus \\
\hline $\begin{array}{l}\text { Muñoz-Villamizar et al. } \\
\text { (2019A) [51] }\end{array}$ & $\begin{array}{l}\text { Trends and gaps for integrating lean and } \\
\text { green management in the agri-food sector }\end{array}$ & 1990-2017 & 117 & $\begin{array}{l}\text { agri-food } \\
\text { sector }\end{array}$ \\
\hline Oliveira et al. (2018) [52] & $\begin{array}{l}\text { Lean and green approach: An evaluation tool } \\
\text { for new product development focused on } \\
\text { small and medium enterprises }\end{array}$ & 2007-2018 & 194 & $\begin{array}{l}\text { small medium } \\
\text { enterprises } \\
(\mathrm{SME})\end{array}$ \\
\hline R. B. R. et al. (2019) [53] & $\begin{array}{l}\text { State of art perspectives of lean and } \\
\text { sustainable manufacturing }\end{array}$ & 1950-2017 & 80 & \\
\hline Rymaszewska (2016) [54] & $\begin{array}{l}\text { Development Perspectives on Improved } \\
\text { Environmental Performance through Lean } \\
\text { Philosophy }\end{array}$ & $\mathrm{N} / \mathrm{A}$ & $\mathrm{N} / \mathrm{A}$ & \\
\hline Saieg et al. (2018) [55] & $\begin{array}{l}\text { Interactions of Building Information } \\
\text { Modeling, Lean and Sustainability on the } \\
\text { Architectural, Engineering and Construction } \\
\text { industry: A systematic review }\end{array}$ & 2000-2015 & 32 & $\begin{array}{c}\text { lean } \\
\text { construction }\end{array}$ \\
\hline Siegel et al. (2019) [56] & $\begin{array}{l}\text { Integrated green lean approach and } \\
\text { sustainability for SMEs: From literature } \\
\text { review to a conceptual framework }\end{array}$ & $2000-2018$ & 45 & $\begin{array}{l}\text { small medium } \\
\text { enterprises } \\
(\mathrm{SME})\end{array}$ \\
\hline $\begin{array}{l}\text { Solaimani and Sedighi } \\
\text { (2020) [57] }\end{array}$ & $\begin{array}{l}\text { Toward a holistic view on lean sustainable } \\
\text { construction: A literature review }\end{array}$ & 1998-2017 & 118 & $\begin{array}{c}\text { lean } \\
\text { construction }\end{array}$ \\
\hline Sony (2019) [58] & $\begin{array}{l}\text { Implementing sustainable operational } \\
\text { excellence in organizations: an integrative } \\
\text { viewpoint }\end{array}$ & 1988-2018 & 44 & $\begin{array}{l}\text { operational } \\
\text { excellence }\end{array}$ \\
\hline Taddeo et al. (2019) [59] & $\begin{array}{l}\text { A bibliometric and network analysis of Lean } \\
\text { and Clean(er) production research } \\
(1990 / 2017)\end{array}$ & 1990-2017 & 281 & \\
\hline $\begin{array}{l}\text { Wichaisri and Sopadang } \\
\text { (2018) [60] }\end{array}$ & $\begin{array}{l}\text { Trends and Future Directions in Sustainable } \\
\text { Development }\end{array}$ & 1997-2015 & 677 & \\
\hline
\end{tabular}

Most reviews assume a positive relationship between lean and sustainability. Lean methods and lean applications are considered to contribute to resource efficiency and cleaner production and, hence, to business development towards sustainability. Sustainability effects mentioned in the reviews are often savings in materials and energy resulting from various optimizations and the avoidance of waste. For instance, methods of the zero defects principle, such as Six Sigma and Poka Yoke, avoid scrap and consequently reduce emissions and increase resource efficiency.

Some of the existing studies mention specific lean methods (e.g., [42]), but fail to provide a systematic overview nor any classification with regard to corporate sustainability. This confirms the need for a thorough investigation of lean methods and corporate sustainability as well as verifies the research questions of this paper.

\subsection{Prevalence of Lean Methods and Concepts in Sustainability Contexts}

Figure 3 depicts the frequency of lean methods mentioned within the 363 publications on lean and sustainability. The just in time method is mentioned in $58 \%$ of all publications, followed by value stream mapping with $47 \%$, and Six Sigma with $40 \%$. A total of 28 methods are mentioned in at least one publication, while nine lean methods, including, e.g., chaku chaku and U layout, are not mentioned at all. 


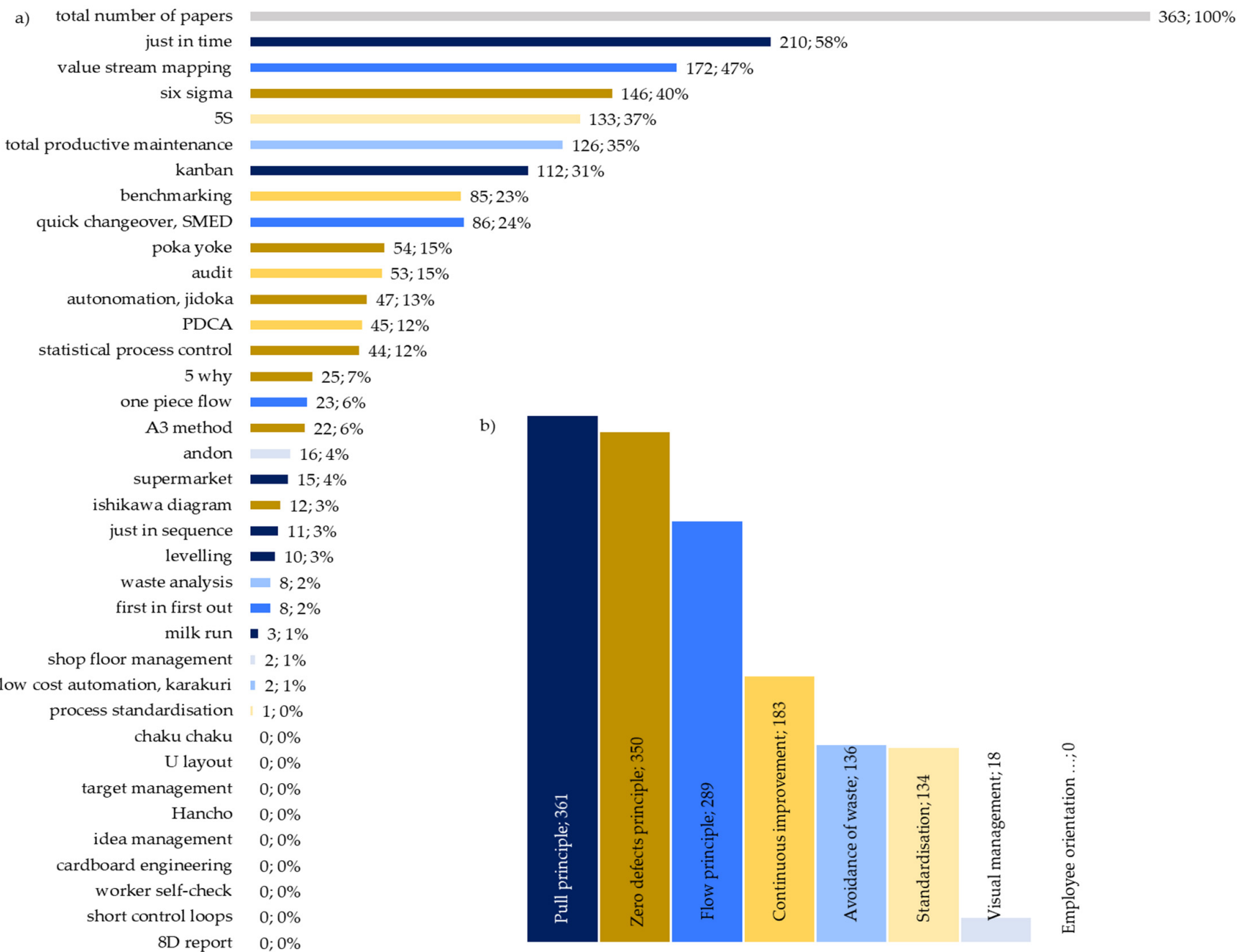

Figure 3. Frequency of lean methods (a) and principles (b) in publications on lean and corporate sustainability; colors represent lean principles.

Figure 3 also groups the methods according to the lean principles following the VDI 2870 guideline [11]. Each lean method is counted only once per paper, no matter how many times it is mentioned. The total of 1471 references to lean methods by 363 publications equals an average mentioning of 4 different methods per publication. The pull principle (361 mentions) and the zero defects principle ( 350 mentions) are the most common lean principles with each about one-fourth of all references. This is followed by the flow principle (289 mentions) and continuous improvement (183 mentions). The least frequently mentioned principle is employee orientation and management by objectives, with not a single mention in either of the two included methods.

A matrix included in the Supplementary Material shows the individual lean methods in each paper.

\subsection{Sustainability Characteristics of Lean Case Studies}

All 363 publications were screened for "real world" case studies, i.e., descriptions of lean implementation within company settings. The 81 publications that included case study content were subjected to a full text analysis for identifying common features and corporate sustainability characteristics within the cases (cp. Table 3). A table with the detailed analysis of the case studies is included in the Supplementary Material. 
Table 3. The common features and corporate sustainability characteristics of the lean and sustainability case studies.

\begin{tabular}{|c|c|c|c|}
\hline Categories & Features and Characteristics & Frequency & Percentage \\
\hline Case study total & & 81 & $10.0 \%$ \\
\hline \multirow{7}{*}{$\begin{array}{l}\text { Sustainability } \\
\text { dimension }\end{array}$} & ecological only & 38 & $46.9 \%$ \\
\hline & ecological + economic & 20 & $24.7 \%$ \\
\hline & all three dimensions & 14 & $17.3 \%$ \\
\hline & ecological + social & 9 & $11.1 \%$ \\
\hline & economic only & 0 & $0.0 \%$ \\
\hline & economic + social & 0 & $0.0 \%$ \\
\hline & social only & 0 & $0.0 \%$ \\
\hline \multirow{4}{*}{ System boundary } & application within one & & \\
\hline & $\begin{array}{l}\text { company only (plus one } \\
\text { study in a city) }\end{array}$ & 69 & $85.2 \%$ \\
\hline & $\begin{array}{l}\text { application incl. upstream } \\
\text { processes (supplier etc.) }\end{array}$ & 7 & $8.6 \%$ \\
\hline & $\begin{array}{l}\text { application incl. downstream } \\
\text { processes (customers etc.) }\end{array}$ & 5 & $6.2 \%$ \\
\hline \multirow{6}{*}{$\begin{array}{c}\text { Most frequent } \\
\text { sustainability effects } \\
\text { (multiple effects } \\
\text { possible) }\end{array}$} & energy savings & 38 & $46.9 \%$ \\
\hline & material savings & 33 & $40.7 \%$ \\
\hline & emission reduction & 30 & $37.0 \%$ \\
\hline & waste reduction & 30 & $37.0 \%$ \\
\hline & cost reduction & 22 & $27.2 \%$ \\
\hline & water use reduction & 19 & $23.5 \%$ \\
\hline \multirow{3}{*}{$\begin{array}{l}\text { Most frequent lean } \\
\text { methods }\end{array}$} & value stream mapping (VSM) & 34 & $42.0 \%$ \\
\hline & Six Sigma & 12 & $14.8 \%$ \\
\hline & $\begin{array}{c}\text { single minute exchange of } \\
\text { die (SMED) }\end{array}$ & 7 & $8.6 \%$ \\
\hline
\end{tabular}

The vast majority of case studies describes applications in manufacturing companies with a huge variety of products and industries covered. Automotive, metal processing, electronics manufacturing, paper, and food are mentioned several times. Furthermore, four case studies from the construction industry and two from the logistics sector can be identified.

The full text analysis illustrates that all case studies deal with the environmental dimension of sustainability; hence, no study focuses on the social and/or economic dimension alone. The ecological dimension is combined with the economic dimension in 20 cases and with the social dimension in 9 cases. All 3 dimensions of sustainability are combined in 14 case studies.

All case studies describe one or more application(s) within a single company, while less than $15 \%$ of the studies consider either downstream or upstream supply chain actors and processes. Most case studies report results of applying lean methods with regard to sustainability qualitatively, quantitatively, or both. Energy savings are the most frequently mentioned sustainability-related effect of applying lean, followed by material savings, emission reductions, and water use decrease. The fact that cost savings and waste reduction are also on the list of most frequently reported effects mirrors the stronghold of the ecological and economic as well as the absence of the social dimension of sustainability, as mentioned before. The sustainability effects are often measured in specific indicators including energy savings in MWh/a (e.g., [61]), water savings in m3 (e.g., [62]), or Carbon Footprint in $\mathrm{kg} \mathrm{CO}$-eq. (e.g., [63]).

While just in time is the most frequently mentioned method in all papers on lean and sustainability, value stream mapping dominates the case studies, followed by Six Sigma and single minute exchange of die (SMED). The case studies also feature adaptations and refinements of lean methods for sustainability purposes, e.g., "sustainable value stream mapping" [64], "energy value stream mapping" [65,66], "environmental value 
stream mapping" [67] and "resource value stream mapping" [68], and combinations of lean and sustainability methods, e.g., combinations of quick changeover (SMED) and carbon footprint [69], or Six Sigma and environmental life cycle assessment [70].

\section{Discussion and Interpretation}

This literature review was conducted as a standardized analysis with clear framework conditions using pertinent literature databases and full text access for all query results. The disregard of non-English language publications and publications not listed in the literature databases could be considered a limitation of this research.

The results of this literature review complement existing research on lean and sustainability by systematically analyzing specific lean methods in the context of sustainability and by further exploring the sustainability characteristics of such lean applications. The triangulation of the identified 47 meta studies additionally showed the relevance and result of the interrelationships between lean and sustainability.

Within corporate sustainability, various lean methods could be of relevance, e.g., to increase energy and resource efficiency. A detailed overview of the qualitative and quantitative sustainability effects of the lean applications is provided in the Supplementary Material. It is noticeable that certain lean methods are mentioned more frequently than others (cp. Figure 3). Overall, this is consistent with the experience of the authors regarding the frequency of use of specific lean methods. However, it is surprising that certain methods are mentioned in detail only very rarely, even though they appear to be clearly related to sustainability.

JIT, or just in time, occurs most frequently, which points to the ambivalence of the method from a sustainability point of view, where the reduction of storage space and over-ordering is offset by the environmental impact of additional transport processes. The high frequency of the JIT-Principle (210 references) can furthermore be explained by its high relevance for lean and production systems in general [71] (p. 145), [7] (p. 69).

A powerful and often used lean analysis method is value stream mapping (172 references), which combines information and material flows, determines key figures, and identifies wastage. The full text analysis of lean case studies in the context of sustainability shows that value stream mapping is further developed in terms of sustainable, energy, or environmental value stream maps as in $[64,66]$. Other lean methods remain underrepresented in terms of their further development. Furthermore, value stream mapping is predestined for a combination with sustainability methods such as material flow cost accounting, but only two combinations are described for this purpose in case studies. Material flow cost accounting maps material and energy flows of a production system and assigns all related costs to the products of the system and materials losses, in order to identify the cost saving potentials of resource efficiency measures [72,73].

Surprisingly, the lean principle autonomation (jidoka), which is historically older than JIT, is only ranked in the middle range (47 references). Jidoka stops machines or processes before defects are produced to avoid the passing on of errors [74] (pp. 69-70), which inevitably leads to environmental performance improvements by avoiding wastage material and energy.

An unexpectedly low named method with only three mentions is the milk run [75] (pp. 236-237). Empty runs and the number of trips can be reduced in both the supply chain and internal factory logistics. The little attention paid to this methodology may also be attributed to the relatively low application of lean methods in supply chain contexts. About $85 \%$ of all case studies focus solely on the operations of one company, without considering any downstream or upstream aspects (Table 3). Neither from a lean nor sustainability perspective is the focus on the operation processes of a single company sufficient. Lean implementation often follows the so-called "line back" approach [76] (p. 113), which means that lean methods are applied for an assembly line and then gradually expanded to logistics, further areas of the factory, and towards suppliers. Likewise, methodologies of sustainability require a whole life cycle perspective, which includes the direct supply chain 
and even further up- and downstream processes of environmental and social relevance (e.g., [77]). The very low number of lean applications that include up- or downstream aspects show that there is still a lot of potential for further development in this area.

Karakuri is a widespread lean method and combines the characteristics of kaizen and sustainability [78]. By using natural forces, such as gravity, spring force, or magnetism, karakuri helps to save resources and energy. Thus, karakuri has a strong connection to sustainable implementations and solutions [79]. Synonyms for karakuri are low cost automation (LCA) and low cost intelligent automation (LCIA). The karakuri methods, as well as LCA and LCIA, are mentioned in only 2 out of 363 publications and are not discussed in-depth.

The lean method U-layout ( $\mathrm{U}$ cell) [80] (pp. 71-79) is not specified in any of the identified publications. From a sustainability point of view, using small flexible assembly cells offer advantages, in particular in combination with the assembly method chaku chaku [74] (p. 70), which is not mentioned within any of the 363 publications. $U$ cells and chaku chaku reduce distances for people and logistics, and at lower volumes, so individual cells can be completely shut down in terms of energy savings.

In general, this literature review shows that the main interface of lean and sustainability lies in the operational and production-related area and is, thus, closely related to resource- and eco-efficiency. Therefore, the ecological and economic dimensions of sustainability, plus the combination of both, clearly outweigh the social dimension (which is merely a side note). This finding is in line with previous literature reviews (e.g., $[25,39,48]$ ). However, this disregards the fact that lean methods, e.g., through ergonomics, can have a direct influence on social performance in terms of worker protection and satisfaction and can, thus, contribute very well to sustainability. Moreover, the operational focus of the lean and sustainability interface neglects the potential advantages and disadvantages of lean in unforeseeable and disruptive changes of the business environment. In consequence, this literature review does not provide answers to whether lean strengthens or weakens the resilience of supply chain systems in situations such as the current pandemic.

\section{Conclusions and Outlook}

Within a systematic literature review, papers at the interface of lean and sustainability have been identified to analyze the application of lean methods in the context of corporate sustainability. The quantitative analysis shows the prevalence of only a few lean methods, such as just in time and value stream mapping. Other methods, such as karakuri, milk run, or chaku chaku, are mentioned only very rarely, even though they appear to be clearly related to sustainability. The in-depth analysis of case studies has revealed a focus on intra-company applications and effects regarding the ecological dimension of sustainability. Upstream and downstream processes in the supply chain, as well as social implications for lean methods and concepts, remain underrepresented.

The combination of lean and sustainability is a current and relevant topic for practice. Sustainability in manufacturing companies is increasingly coming into focus. In this context, ecological and economic issues go hand in hand. As shown in the case studies, lean also has an impact on corporate sustainability and the saving of resources and greenhouse gases.

Further research topics can be derived from the results of this literature review. A promising next research step is to analyze the impact mechanisms of lean methods on sustainability performance. How does lean impact different aspects of sustainability and what is the measurable impact? Which sustainability metrics are affected? This opens up opportunities for conceptual work as well as for empirical research in the form of systematic surveys of companies that already apply lean methods and measure sustainability performance. A more detailed investigation into the potential of individual lean methods in the context of sustainability is another promising field of research. Here, case studies on the use and benefits of karakuri, for example, could improve the state of research.

The findings could be incorporated into the development of an integrated framework of lean and sustainability concepts and methods, which considers the entire value chain 
and starts at the early innovation stages and product development processes. Such a framework embraces the social dimension of sustainability, as lean methods and principles also focus on social aspects and people.

In the near future, the success of lean methods will also depend on their ability to contribute to corporate sustainability. This requires a systematic integration of lean and sustainability, which this paper is aimed at contributing to.

Supplementary Materials: Additional data is supplied with this article as supplementary material. The following are available online at https:/ / www.mdpi.com/article/10.3390/su132212786/s1, Supplementray_material.xlsx: Sheet S1: List of Publications (complete list of all papers with information on authors, publisher, DOI, etc.), Sheet S2: Lean Methods Matrix, and Sheet S3: Analysis Case Studies.

Author Contributions: Conceptualization, F.B., I.R. and T.V.; methodology, K.H. and I.R.; validation, F.B. and K.H.; formal analysis, F.B., I.R. and K.H.; investigation, I.R. and K.H.; writing-original draft preparation, F.B., I.R. and K.H.; writing-review and editing, F.B., K.H. and T.V.; visualization, F.B., I.R. and T.V.; supervision, F.B. and T.V. All authors have read and agreed to the published version of the manuscript.

Funding: This research received no external funding.

Institutional Review Board Statement: Not applicable.

Informed Consent Statement: Not applicable.

Conflicts of Interest: The authors declare no conflict of interest.

\section{References}

1. United Nations. Transforming Our World: The 2030 Agenda for Sustainable Development: A/RES/70/1. Available online: https:/ / sustainabledevelopment.un.org/content/documents/21252030\%20Agenda\%20for\%20Sustainable\%20Development $\%$ 20web.pdf (accessed on 5 July 2021).

2. Mio, C.; Panfilo, S.; Blundo, B. Sustainable development goals and the strategic role of business: A systematic literature review. Bus. Strategy Environ. 2020, 29, 3220-3245. [CrossRef]

3. Elkington, J. Cannibals with Forks: The Triple Bottom Line of 21st Century Business; Capstone: Oxford, UK, 1997; ISBN 1-900961-27-X.

4. Meuer, J.; Koelbel, J.; Hoffmann, V.H. On the Nature of Corporate Sustainability. Organ. Environ. 2020, 33, 319-341. [CrossRef]

5. Gasper, D.; Shah, A.; Tankha, S. The Framing of Sustainable Consumption and Production in SDG 12. Glob. Policy 2019, 10, 83-95. [CrossRef]

6. Womack, J.P.; Jones, D.T.; Roos, D. The Machine That Changed the World; Rawson Associates: New York, NY, USA, 1990; ISBN 9780060974176.

7. Shingō, S. A Study of the Toyota Production System: From an Industrial Engineering Viewpoint; Productivity Press: New York, NY, USA, 1989; ISBN 9780915299171.

8. Garza-Reyes, J.A.; Kumar, V.; Chaikittisilp, S.; Tan, K.H. The effect of lean methods and tools on the environmental performance of manufacturing organisations. Int. J. Prod. Econ. 2018, 200, 170-180. [CrossRef]

9. Liker, J.K. The Toyota Way: 14 Management Principles from the World's Greatest Manufacturer; McGraw-Hill: New York, NY, USA, 2004; ISBN 9780071392310.

10. Clarke, C. Automotive Production Systems and Standardisation: From Ford to the Case of Mercedes-Benz; Physica-Verlag HD: Heidelberg, Germany, 2005; ISBN 978-3-7908-1578-8.

11. VDI. VDI 2870 Lean Production Systems: Basic Principles, Introduction, and Review; Beuth: Berlin, Germany, 2012; ICS 03.100.50.

12. Denyer, D.; Tranfield, D. Producing a Systematic Review. In The Sage Handbook of Organizational Research Methods; Buchanan, D.A., Bryman, A., Eds.; Sage: Los Angeles, CA, USA, 2009; pp. 671-689; ISBN 978-1-4462-0064-3.

13. Jesson, J.K.; Matheson, L.; Lacey, F.M. Doing your Literature Review: Traditional and Systematic Techniques; SAGE Publications: Los Angeles, CA, USA, 2011; ISBN 9781848601536.

14. Carvajal-Arango, D.; Bahamón-Jaramillo, S.; Aristizábal-Monsalve, P.; Vásquez-Hernández, A.; Botero, L.F.B. Relationships between lean and sustainable construction: Positive impacts of lean practices over sustainability during construction phase. $J$. Clean. Prod. 2019, 234, 1322-1337. [CrossRef]

15. Johansson, G.; Sundin, E. Lean and green product development: Two sides of the same coin? J. Clean. Prod. 2014, 85, 104-121. [CrossRef]

16. Baliga, R.; Raut, R.; Kamble, S. The effect of motivators, supply, and lean management on sustainable supply chain management practices and performance. Benchmarking: Int. J. 2020, 27, 347-381. [CrossRef]

17. Hallam, C.; Contreras, C. Integrating lean and green management. Manag. Decis. 2016, 54, 2157-2187. [CrossRef]

18. Jamil, A.H.A.; Fathi, M.S. The Integration of Lean Construction and Sustainable Construction: A Stakeholder Perspective in Analyzing Sustainable Lean Construction Strategies in Malaysia. Procedia Comput. Sci. 2016, 100, 634-643. [CrossRef] 
19. Cherrafi, A.; Elfezazi, S.; Garza-Reyes, J.A.; Benhida, K.; Mokhlis, A. Barriers in Green Lean implementation: A combined systematic literature review and interpretive structural modelling approach. Prod. Plan. Control. 2017, 28, 829-842. [CrossRef]

20. Alves, A.; Moreira, F.; Abreu, F.; Colombo, C. Sustainability, Lean and Eco-Efficiency Symbioses. In Multiple Helix Ecosystems for Sustainable Competitiveness; Peris-Ortiz, M., Ferreira, J.J., Farinha, L., Fernandes, N.O., Eds.; Springer International Publishing: Cham, Switzerland, 2016; pp. 91-112. ISBN 978-3-319-29675-3.

21. Babalola, O.; Ibem, E.O.; Ezema, I.C. Implementation of lean practices in the construction industry: A systematic review. Build. Environ. 2019, 148, 34-43. [CrossRef]

22. Bhatt, Y.; Ghuman, K.; Dhir, A. Sustainable manufacturing. Bibliometrics and content analysis. J. Clean. Prod. 2020, 260, 120988. [CrossRef]

23. Bhattacharya, A.; Nand, A.; Castka, P. Lean-green integration and its impact on sustainability performance: A critical review. J. Clean. Prod. 2019, 236, 117697. [CrossRef]

24. Caldera, H.; Desha, C.; Dawes, L. Exploring the role of lean thinking in sustainable business practice: A systematic literature review. J. Clean. Prod. 2017, 167, 1546-1565. [CrossRef]

25. Cherrafi, A.; Elfezazi, S.; Chiarini, A.; Mokhlis, A.; Benhida, K. The integration of lean manufacturing, Six Sigma and sustainability: A literature review and future research directions for developing a specific model. J. Clean. Prod. 2016, 139, 828-846. [CrossRef]

26. Chugani, N.; Kumar, V.; Garza-Reyes, J.A.; Rocha-Lona, L.; Upadhyay, A. Investigating the green impact of Lean, Six Sigma and Lean Six Sigma. Int. J. Lean Six Sigma 2017, 8, 7-32. [CrossRef]

27. Ciccullo, F.; Pero, M.; Caridi, M.; Gosling, J.; Purvis, L. Integrating the environmental and social sustainability pillars into the lean and agile supply chain management paradigms: A literature review and future research directions. J. Clean. Prod. 2018, 172, 2336-2350. [CrossRef]

28. Cruz-Villazon, C.; Otegi-Olaso, J.R.; Aguilar-Fernandez, M.E.; Fuentes-Ardeo, L. Lean Thinking: A Useful Tool to Integrate Sustainability into Project Management. In Project Management and Engineering Research; Ayuso Muñoz, J.L., Yagüe Blanco, J.L., Capuz-Rizo, S.F., Eds.; Springer International Publishing: Cham, Switzerland, 2019; pp. 35-48. ISBN 978-3-319-92272-0.

29. Dieste, M.; Panizzolo, R.; Garza-Reyes, J.A.; Anosike, A. The relationship between lean and environmental performance: Practices and measures. J. Clean. Prod. 2019, 224, 120-131. [CrossRef]

30. Duarte, S.; Machado, V.C. Manufacturing paradigms in Supply Chain Management. Int. J. Manag. Sci. Eng. Manag. 2011, 6, 328-342. [CrossRef]

31. Dubey, R.; Ali, S.S. Exploring antecedents of extended supply chain performance measures. Benchmarking: Int. J. 2015, 22, 752-772. [CrossRef]

32. Dües, C.M.; Tan, K.H.; Lim, M. Green as the new Lean: How to use Lean practices as a catalyst to greening your supply chain. J. Clean. Prod. 2013, 40, 93-100. [CrossRef]

33. Engin, B.E.; Martens, M.; Paksoy, T. Lean and Green Supply Chain Management: A Comprehensive Review. In Lean and Green Supply Chain Management; Paksoy, T., Weber, G.-W., Huber, S., Eds.; Springer International Publishing: Cham, Switzerland, 2019; pp. 1-38; ISBN 978-3-319-97510-8.

34. Farias, L.M.S.; Santos, L.C.; Gohr, C.F.; de Oliveira, L.C.; Da Amorim, M.H.S. Criteria and practices for lean and green performance assessment: Systematic review and conceptual framework. J. Clean. Prod. 2019, 218, 746-762. [CrossRef]

35. de Freitas, J.G.; Costa, H.G. Impacts of Lean Six Sigma over organizational sustainability. Int. J. Lean Six Sigma 2017, 8, 89-108. [CrossRef]

36. Gaikwad, L.; Sunnapwar, V. An integrated Lean, Green and Six Sigma strategies. TQM J. 2020, 32, 201-225. [CrossRef]

37. Garza-Reyes, J.A. Lean and green-a systematic review of the state of the art literature. J. Clean. Prod. 2015, 102, 18-29. [CrossRef]

38. Garza-Reyes, J.A. Green lean and the need for Six Sigma. Int. J. Lean Six Sigma 2015, 6, 226-248. [CrossRef]

39. Hartini, S.; Ciptomulyono, U. The Relationship between Lean and Sustainable Manufacturing on Performance: Literature Review. Procedia Manuf. 2015, 4, 38-45. [CrossRef]

40. Henao, R.; Sarache, W.; Gómez, I. Lean manufacturing and sustainable performance: Trends and future challenges. J. Clean. Prod. 2019, 208, 99-116. [CrossRef]

41. de Souza, J.P.E.; Dekkers, R. Adding Sustainability to Lean Product Development. Procedia Manuf. 2019, 39, 1327-1336. [CrossRef]

42. Kaswan, M.S.; Rathi, R. Analysis and modeling the enablers of Green Lean Six Sigma implementation using Interpretive Structural Modeling. J. Clean. Prod. 2019, 231, 1182-1191. [CrossRef]

43. Li, S.; Fang, Y.; Wu, X. A systematic review of lean construction in Mainland China. J. Clean. Prod. 2020, 257, 120581. [CrossRef]

44. Lopes de Sousa Jabbour, A.B.; Ndubisi, N.O.; Roman Pais Seles, B.M. Sustainable development in Asian manufacturing SMEs: Progress and directions. Int. J. Prod. Econ. 2020, 225, 107567. [CrossRef]

45. Marco-Ferreira, A.; Stefanelli, N.O.; Seles, B.M.R.P.; Fidelis, R. Lean and Green: Practices, paradigms and future prospects. Benchmarking Int. J. 2020, 27, 2077-2107. [CrossRef]

46. Marhani, M.A.; Jaapar, A.; Bari, N.A.A.; Zawawi, M. Sustainability Through Lean Construction Approach: A Literature Review. Procedia-Soc. Behav. Sci. 2013, 101, 90-99. [CrossRef]

47. Martínez León, H.C.; Calvo-Amodio, J. Towards lean for sustainability: Understanding the interrelationships between lean and sustainability from a systems thinking perspective. J. Clean. Prod. 2017, 142, 4384-4402. [CrossRef]

48. Martínez-Jurado, P.J.; Moyano-Fuentes, J. Lean Management, Supply Chain Management and Sustainability: A Literature Review. J. Clean. Prod. 2014, 85, 134-150. [CrossRef] 
49. Mellado, F.; Lou, E.C. Building information modelling, lean and sustainability: An integration framework to promote performance improvements in the construction industry. Sustain. Cities Soc. 2020, 61, 102355. [CrossRef]

50. Mollenkopf, D.; Stolze, H.; Tate, W.L.; Ueltschy, M. Green, lean, and global supply chains. Int. J. Phys. Distrib. Logist. Manag. 2010, 40, 14-41. [CrossRef]

51. Muñoz-Villamizar, A.; Santos, J.; Grau, P.; Viles, E. Trends and gaps for integrating lean and green management in the agri-food sector. Br. Food J. 2019, 121, 1140-1153. [CrossRef]

52. Oliveira, G.A.; Tan, K.H.; Guedes, B.T. Lean and green approach: An evaluation tool for new product development focused on small and medium enterprises. Int. J. Prod. Econ. 2018, 205, 62-73. [CrossRef]

53. Vinodh, S.; Asokan, P. State of art perspectives of lean and sustainable manufacturing. Int. J. Lean Six Sigma 2019, 10, 234-256. [CrossRef]

54. Rymaszewska, A. Development perspectives on improved environmental performance through lean philosophy. Int. J. Sustain. Econ. 2016, 8, 208-223. [CrossRef]

55. Saieg, P.; Sotelino, E.D.; Nascimento, D.; Caiado, R.G.G. Interactions of Building Information Modeling, Lean and Sustainability on the Architectural, Engineering and Construction industry: A systematic review. J. Clean. Prod. 2018, 174, 788-806. [CrossRef]

56. Siegel, R.; Antony, J.; Garza-Reyes, J.A.; Cherrafi, A.; Lameijer, B. Integrated green lean approach and sustainability for SMEs: From literature review to a conceptual framework. J. Clean. Prod. 2019, 240, 118205. [CrossRef]

57. Solaimani, S.; Sedighi, M. Toward a holistic view on lean sustainable construction: A literature review. J. Clean. Prod. 2020, 248, 119213. [CrossRef]

58. Sony, M. Implementing sustainable operational excellence in organizations: An integrative viewpoint. Prod. Manuf. Res. 2019, 7, 67-87. [CrossRef]

59. Taddeo, R.; Simboli, A.; Di Vincenzo, F.; Ioppolo, G. A bibliometric and network analysis of Lean and Clean(er) production research (1990/2017). Sci. Total Environ. 2019, 653, 765-775. [CrossRef] [PubMed]

60. Wichaisri, S.; Sopadang, A. Trends and Future Directions in Sustainable Development. Appl. Energy 2018, 26, 1-17. [CrossRef]

61. Braglia, M.; Castellano, D.; Gabbrielli, R.; Marrazzini, L. Energy Cost Deployment (ECD): A novel lean approach to tackling energy losses. J. Clean. Prod. 2020, 246, 119056. [CrossRef]

62. Vais, A.; Miron, V.; Pedersen, M.; Folke, J. "Lean and Green" at a Romanian secondary tissue paper and board mill-putting theory into practice. Resour. Conserv. Recycl. 2005, 46, 44-74. [CrossRef]

63. Marrucci, L.; Marchi, M.; Daddi, T. Improving the carbon footprint of food and packaging waste management in a supermarket of the Italian retail sector. Waste Manag. 2020, 105, 594-603. [CrossRef] [PubMed]

64. Hartini, S.; Ciptomulyono, U.; Anityasari, M. Manufacturing sustainability assessment using a lean manufacturing tool: A case study in the Indonesian wooden furniture industry. Int. J. Lean Six Sigma 2020, 11, 943-971. [CrossRef]

65. Verma, N.; Sharma, V. Energy Value Stream Mapping a Tool to Develop Green Manufacturing. Procedia Eng. 2016, 149, 526-534. [CrossRef]

66. Baysan, S.; Kabadurmus, O.; Cevikcan, E.; Satoglu, S.I.; Durmusoglu, M.B. A simulation-based methodology for the analysis of the effect of lean tools on energy efficiency: An application in power distribution industry. J. Clean. Prod. 2019, 211, 895-908. [CrossRef]

67. Litos, L.; Borzillo, F.; Patsavellas, J.; Cockhead, D.; Salonitis, K. Management Tool Design for Eco-efficiency Improvements in Manufacturing-A Case Study. Procedia CIRP 2017, 60, 500-505. [CrossRef]

68. Papetti, A.; Menghi, R.; Di Domizio, G.; Germani, M.; Marconi, M. Resources value mapping: A method to assess the resource efficiency of manufacturing systems. Appl. Energy 2019, 249, 326-342. [CrossRef]

69. Leme, R.D.; Nunes, A.O.; Message Costa, L.B.; Silva, D.A.L. Creating value with less impact: Lean, green and eco-efficiency in a metalworking industry towards a cleaner production. J. Clean. Prod. 2018, 196, 517-534. [CrossRef]

70. Banawi, A.; Bilec, M.M. A framework to improve construction processes: Integrating Lean, Green and Six Sigma. Int. J. Constr. Manag. 2014, 14, 45-55. [CrossRef]

71. Imai, M. Gemba Kaizen: A Commonsense Low-Cost Approach to Management; McGraw-Hill: New York, NY, USA, 1997; ISBN 978-0070314467.

72. ISO. ISO 14051. Environmental Management-Material Flow Cost Accounting—General Framework; International Organization for Standardization: Geneva, Switzerland, 2011; pp. 1-38.

73. Schmidt, M.; Nakajima, M. Material Flow Cost Accounting as an Approach to Improve Resource Efficiency in Manufacturing Companies. Resources 2013, 2, 358-369. [CrossRef]

74. Helmold, M. Lean Management and Kaizen: Fundamentals from Cases and Examples in Operations and Supply Chain Management; Springer International Publishing: Cham, Switzerland, 2020; ISBN 978-3-030-46980-1.

75. Minner, S. Inbound Logistics. In Operations, Logistics and Supply Chain Management; Zijm, H., Klumpp, M., Regattieri, A., Heragu, S., Eds.; Springer International Publishing: Cham, Switzerland, 2019; pp. 233-249; ISBN 978-3-319-92446-5.

76. Ivanov, D.; Tsipoulanidis, A.; Schönberger, J. Sourcing Strategy. In Global Supply Chain and Operations Management: A DecisionOriented Introduction to the Creation of Value, 2nd ed.; Ivanov, D., Tsipoulanidis, A., Schönberger, J., Eds.; Springer International Publishing: Cham, Switzerland, 2019; pp. 111-134; ISBN 978-3-319-94312-1.

77. Mazzi, A. Introduction. Life cycle thinking. In Life Cycle Sustainability Assessment for Decision-Making; Ren, J., Toniolo, S., Eds.; Elsevier: Amsterdam, The Netherlands, 2020; pp. 1-19; ISBN 9780128183557. 
78. Toyota. Toyota News 152 Using Karakuri to Achieve the Ultimate in Carbon Neutrality. Available online: https:/ / toyotatimes.jp/ en/insidetoyota/152.html (accessed on 5 July 2021).

79. Katayama, H.; Sawa, K.; Hwang, R.; Ishiwatari, N.; Hayashi, N. Analysis and classification of Karakuri technologies for reinforcement of their visibility, improvement and transferability: An attempt for enhancing lean management. In Proceedings of the PICMET '14 Conference: Portland International Center for Management of Engineering and Technology; Infrastructure and Service Integration, Kanazawa, Japan, 27-31 July 2014; pp. 1895-1906.

80. Seifermann, S.; Böllhoff, J.; Adolph, S.; Abele, E.; Metternich, J. Flexible Design of Lean Production Systems in Response to Fluctuations Due to Logistics and Traffic. In Dynamic and Seamless Integration of Production, Logistics and Traffic: Fundamentals of Interdisciplinary Decision Support; Abele, E., Boltze, M., Pfohl, H.-C., Eds.; Springer International Publishing: Cham, Switzerland, 2017; pp. 51-82; ISBN 978-3-319-41095-1. 